\title{
THE RELATIONSHIP BETWEEN COWORKER SUPPORTS, QUALITY OF WORK LIFE AND WELLBEING: AN EMPIRICAL STUDY OF HOTEL EMPLOYEES
}

\author{
Assoc. Prof. Nilgün AVCI
}

Ege University, The School of Cesme Tourism and Hotel Management, İzmir, Turkey (nilgun.avci@ege.edu.tr)

\begin{abstract}
This study aims to explore the relationship coworker supports, employee quality of work life, and wellbeing. In the field study research, data were collected hotels employee in Cesme, Izmir. The analysis revealed that coworker support, employee quality of work life and wellbeing correlated positively. In the analysis, it was noticed that, coworker support and employee quality of work life effects on wellbeing. The findings of the study will provide the importance of coworker support and quality of work life on employee wellbeing in hotels. These conclusions may be helpful for hotel human resources managers in increasing the employee wellbeing.
\end{abstract}

Keywords: Coworker Support, Quality of Work Life, Wellbeing, Hotels, Cesme.

\section{ÇALIŞMA ARKADAŞI DESTEĞİ, İ̧̧ YAŞAMI KALITESİ VE ÇALIŞANLARIN REFAHI ARASINDAKİ İLIŞKİ: OTEL ÇALIŞANLARI UYGULAMASI}

\begin{abstract}
ÖZET
Bu çalışmanın amacı, çalışma arkadaşları desteği, iş yaşam kalitesi ve refah ilişkisini araştırmaktır. Alan araştırmasında kullanılan veriler İzmir Çeşme'de bulunanan otel çalışanlarından toplanmıştır. Yapılan analizler çalışma arkadaşları desteğ $i$, iş yaşam kalitesi ve refah arasında olumlu ilişkinin varlığını ortaya koymuştur. Analizde, çalışma arkadaşlarının desteği ve iş yaşam kalitesinin çalışanların refahında etkili olduğu belirlenmiştir. Çalışmanın bulguları otel işletmelerinde çalışma arkadaşlarının desteği ve iş yaşam kalitesinin çalışanların refahında önemini vurgulamıştır. Bu sonuçlar, otel insan kaynaklart yönetimine çalışanların refahını artırmada yardımcı olabilir.
\end{abstract}

Anahtar Kelimeler: Çalışma Arkadaşlarının Desteği, İş Yaşamı Kalitesi, Çalışanların Refahı, Otel, Çeşme. 


\section{Introduction}

Jobs in the accommodation sector is generally seasonal, labour intensive, repeating, interdependent work, part-time jobs incorporating long working-hour, low social-status, lowpaying, low-quality jobs (Kozak, 1999; Barron et al., 2007; Baum, 2007; Roan \& Diamond, 2003; Wood, 1997) and because of that reasons, job dissatisfaction and the high turnover rate. Without excellent employees, hotel cannot have excellent operations (Enz \& Siguaw, 2000). The industry also emphasizes face to face contact with guests, and the just-in-time nature of service delivery means that hospitality employees are great pressure to respond promptly (Dan, 1990). Hotel human resources management is trying to cope with this challenging complex situation. This complex situation remains important as a research topic.

Research shows that wellbeing affects personal and organizational benefits (Meyer \& Maltin, 2010; Nelson et al., 2014; Van De Voorde et al., 2012; Wright, 2010). Wellbeing is the social, cultural and psychological needs of people, their family, institutions and communities (Buzinde et al., 2014). Analyses have shown that coworker and supervisor support is an important antecedent of job satisfaction (Chiaburu \& Harrison, 2008; Ng \& Sorensen, 2008). Social support from colleagues and supervisors has both direct and indirect positive effects on wellbeing (Bergbom \& Kinnunen, 2014).

Quality of work life (QWL) can increase employee job satisfaction and their performance, reduce absenteeism and employee turnover rate (Sirgy et al., 2001; Wan \& Chan, 2013). The hospitality industry needs to provide a good quality of work life (QWL) in order to attract and retain employees (Kandasamy \& Ancheri, 2009). Researches show the needs to study what contributes to QWL for accommodation employees are necessary in order to enhance the job satisfaction of employees and to reduce their turnover intention.

Limited research, however, has been identified that examined relationship between coworker support, QWL and wellbeing. The purpose of this study is to examine the role of coworker support in employee QWL and wellbeing in hotels. Findings provide suggestions for human resource managers of hotels to improve employee QWL and wellbeing.

\section{Literature Review}

\subsection{Coworker Support}

Coworker support is employees' global beliefs concerning their coworkers' attitudes toward them (Ladd \& Henry, 2000). Coworker support is the extent to which employees believe their coworkers are willing to provide them with work-related assistance to aid in the execution of their service-based duties (Susskind et al., 2003). Cobb (1976) defines social support as "information leading the subject to believe that he is cared for and loved, esteemed, and a member of a network of mutual obligations" (Cobb, 1976).

Coworkers influence working environment, and this influence will affect employee attitudes at work. Coworker support is an important source of employee support in service organisations (Susskind et al., 2007). In service-based organisations support has two main sources, one of them is support from management, the other one is support from coworkers 
(Susskind et al., 2003; Susskind et al., 2007). In spite of organisational and management support is governed by authority ranking coworker support is discretionary (Chiaburu \& Harrison, 2008). Researchers typically devote less attention to studying the role of coworker support than to supervisor support in work attitudes ( $\mathrm{Ng} \&$ Sorensen, 2008). Coworker support can be beneficial for employee wellbeing (Sloan, 2012). Coworker support can influence a meaningful experience for employees whereas negative relations with others can make work life miserable (Chamberlain \& Hodson, 2010; Rumens, 2009). Kales' (2015) study on hotel employees, examines supervisor and peer support on job performance via the mediating roles of job and life satisfaction. The study showed that peer support affect employees life satisfaction.

\subsection{Quality of Work Life (QWL)}

The term QWL, was used first time at an International Labours Relation Conference in 1972 (Hian \& Einstein, 1990). QWL is employee satisfaction with a variety of needs through resources, activities, and outcomes stemming from participation in the workplace (Sirgy et al., 2001). According to May, Lau, \& Johnson (1999) definition of QWL is the conditions of a workplace that support employee satisfaction by providing employees with rewards, job security, and opportunities. Job satisfaction as experienced by employees is therefore closely related to quality of work life. QWL does not only affect job satisfaction but also satisfaction in other life domains such as family life, leisure life, social life, financial life, and so on (Sirgy et al., 2001). Because of having a significant impact on employee behavioural responses, such as organizational identification, job involvement, job satisfaction, job performance, organizational turnover, intention to quit, and personal alienation (Rathi, 2010; Sirgy et al., 2001) QWL studies are important in human resource management. Sirgy et al., (2001) content that QWL be measured in terms of employees' seven needs: (1) health and safety needs; (2) economic; (3) social needs; (4) esteem needs; (5) actualization needs; (6) knowledge needs; and (7) aesthetic needs.

Previous studies have focused on defining QWL and its dimensions (Kandasamy \& Ancheri, 2009; Lewis et al., 2013; Martel \& Dupuis, 2006; Sirgy et al., 2001; Wan \& Chan, 2013) findings showed that different people have different perspectives on defining QWL and QWL has been multidimensional. Some of them are "job security, higher pay, fair reward systems, opportunity, and participative team, work design, work content, and training, career opportunities, participation in decision making, ethical company culture".

Some studies also focused on QWL and job-related attitudes like commitment (Huang et al., 2007; Koonmee et. al., 2010), turnover (Lee et al., 2013; Lee et al., 2013; Ii, Hi, \& Park, 2007; Mosadeghrad, 2013), wellbeing (Rathi, 2010) and they found QWL has positive influence on that attitudes. While there are many studies on QWL, research in the accommodation sector is deficient (Kandasamy \& Ancheri, 2009).

\subsection{Wellbeing}

People are trying to improve their wellbeing in whole life. Because of the importance in human life, managers and resources focuses on wellbeing. Wellbeing is a positive, subjective feeling about life experiences (Andrews \& Withey, 1976), positive psychology (Wright, 2010) and it should be viewed as more than the absence of illness (Monnot \& Beehr, 2014; Meyer 
\& Maltin, 2010). Diener et al. (1999) defines wellbeing as “a broad category of phenomena that includes people's emotional responses, domain satisfactions, and global judgments of life satisfaction". Wellbeing refers to a subjective and good deal of positive and relatively little negative feelings or emotions (Wright, 2010). Researchers have conceptualized wellbeing in terms of other adjectives like pleasantness, life quality, and life satisfaction (Gilbert \& Abdullah, 2004). Life satisfaction as the level of employees' cognitive perception of their subjective well-being (Lee et al.,2016). Work-related wellbeing is particularly relevant as an outcome due to its effect on work motivation (Aerden et al., 2015). Studies pointed out the relationship between wellbeing and, work related behaviours, like employee commitment (Meyer \& Maltin, 2010), job performance (Wright, 2010), job burnout (Lin et al., 2014), employee retention (Wright 2010).

Limited research (example; Simon et al., 2010; Bergboma \& Kinnunen, 2014), however, has paid attention coworker relationship effects on employee wellbeing. This study examines the relationship between coworker support, quality of work life and wellbeing in hotels employee. And also examines the effects of coworker support and quality of work life on wellbeing.

\section{Methods}

\subsection{Respondents and Procedure}

In the study, the quantitative approach was preferred, and the survey technique was used. Firstly, to prepare the survey reviewed the scales used in the empiric studies were analysed in literature. To content validity, the scale was evaluated by five academicians. Data were collected from hotels in Çeşme, Turkey. Data from eight hotels $(3,4$ and 5 stars $)$ during the period of September-November have been applied. Surveys were sent to 500 hotels employee and 325 were received, representing a response rate of $65 \%$.

\subsection{Surveys}

Because the measurement scales were prepared in English and the surveys were administered in Turkey, back-translation was adopted to ensure accuracy of translation. Coworker support were measured using 19-item scale was adopted from previous studies (Ladd \& Henry, 2000; Limpanitgul et al., 2013; Limpanitgul et al., 2014; Chen et al., 2010; Karatepe et al., 2010). Participants were asked to indicate their relationship with coworkers. An example of the items used to measure the "My coworkers are supportive of my goals and values" The Cronbach alpha fort his scale was 0,839 and higher scores indicated. The scale for quality of work life consisted 15-items scale developed by Sirgy et al. (2001) was adopted. Participants were asked to indicate their work life. An example of the items used to measure the "I feel that my job allows me to realize my full potential." The Cronbach alpha fort his scale was 0,887 . With regard to wellbeing of employee, the 8 -items life satisfaction scale Lin et al., (2014), Participants were asked to indicate their wellbeing. An example of the items used to measure the wellbeing is "In most ways my life is close to my ideal." The Cronbach alpha for this scale was 0,877 . The five-point scale ranging which is from 1 (strongly agree) to 5 (strongly disagree) was used for all of the measures. Several demographic characteristics of employees and hotels include gender, age, education, working tenure, hotels class, departments were statistically controlled. 
Skewness and Kurtosis tests used on data to decide if would be used parametric or nonparametric tests can be used. Study's data is distributed normally. To analyse data in frequency distribution, reliability analysis, factor analysis, and correlation by SPSS 20 software program.

\section{Results}

\subsection{Characteristics of Participants}

Descriptive statistics of the sample demographics are on the Table 1. It is seen that $59,1 \%$ of the participants are men, $69,8 \%$ is single and $56,3 \%$ university degree.

Table 1: Participant Profile

\begin{tabular}{cccccc}
\hline Age & Frequency & Percent & Marital Status & Frequency & Percent \\
\hline 20 and younger & 29 & 8,9 & Margie & 98 & 30,2 \\
\hline $\mathbf{2 1 - 3 0}$ & 193 & 59,4 & Single & 227 & 69,8 \\
\hline $\mathbf{3 1 - 4 0}$ & 73 & 22,5 & Education & Frequency & Percent \\
\hline 41 and older & 30 & 9,2 & Primary Education & 21 & 6,5 \\
\hline Sexuality & Frequency & Percent & High School & 121 & 37,2 \\
\hline Woman & 133 & 40,9 & University & 183 & 56,3 \\
\hline Man & 192 & 59,1 & $\begin{array}{c}\text { Year of } \\
\text { Professional Work }\end{array}$ & Frequency & Percent \\
\hline Type of Hotel & Frequency & Percent & Less than 1 year & 28 & 8,6 \\
\hline 5 Stars & 222 & 68,3 & $\mathbf{1 - 3}$ years & 82 & 25,2 \\
\hline 4 Stars & 50 & 15,4 & 4-6 years & 107 & 32,9 \\
\hline 3 Stars & 53 & 16,3 & $\mathbf{7 - 9}$ years & 61 & 18,8 \\
\hline & & & $\mathbf{1 0}$ years and more & 47 & 14,5 \\
\hline
\end{tabular}

\subsection{EFA for the Coworker Support}

Explanatory Factor Analysis (EFA) was used to analyse the construct validity. The factor analysis results have been presented in Table 2 . 
Table 2: Coworker Support Factor Analysis Table

\begin{tabular}{|c|c|c|c|c|c|c|c|}
\hline & 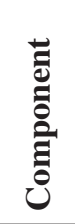 & 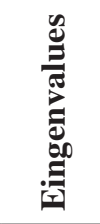 & 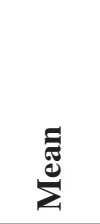 & 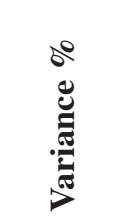 & I & 8 & 2 \\
\hline Factor 1: Coworker Support & & 5,882 & 3,693 & 42,012 & 3,809 & 839 & ,000 \\
\hline $\begin{array}{l}\text { This colleague and I care about each } \\
\text { other's work problems and needs. }\end{array}$ & ,790 & & & & & & \\
\hline $\begin{array}{l}\text { This colleague and I are inclined to } \\
\text { pool our available resources to solve } \\
\text { each other's problems. }\end{array}$ & ,738 & & & & & & \\
\hline $\begin{array}{l}\text { My coworkers are complimentary of } \\
\text { my accomplishment at Work }\end{array}$ & ,737 & & & & & & \\
\hline $\begin{array}{l}\text { I receive help and support from my } \\
\text { coworkers. }\end{array}$ & ,734 & & & & & & \\
\hline I feel comfortable with my coworkers. &, 732 & & & & & & \\
\hline My coworkers back me up when I need it. & ,717 & & & & & & \\
\hline I feel I am accepted in my work group & ,681 & & & & & & \\
\hline $\begin{array}{l}\text { My coworkers really care about my } \\
\text { wellbeing }\end{array}$ & ,681 & & & & & & \\
\hline $\begin{array}{l}\text { My coworkers care about my general } \\
\text { satisfaction at work }\end{array}$ & ,661 & & & & & & \\
\hline $\begin{array}{l}\text { This colleague and I are satisfied with } \\
\text { each other's work. }\end{array}$ & ,646 & & & & & & \\
\hline My coworkers care about my opinions & 617 & & & & & & \\
\hline $\begin{array}{l}\text { This colleague and I are confident in } \\
\text { each other's capability. }\end{array}$ & ,434 & & & & & & \\
\hline $\begin{array}{l}\text { My coworkers are understanding if I } \\
\text { have a bad day }\end{array}$ &, 371 & & & & & & \\
\hline $\begin{array}{l}\text { Help is available from my coworkers } \\
\text { when I have a problem }\end{array}$ &, 303 & & & & & & \\
\hline
\end{tabular}

Kaiser-Meyer-Olkin =0,935; Bartlett's Test of Sphericity = 1574,918; Cumulative Variance: 42,012

According to the EFA for coworker support Bartlett's Test Result is 1574,918 . KaiserMeyer- Olkin (KMO) Sampling Value is 0,935 , and sufficient to apply factor analysis method. 


\subsection{EFA for the Quality of Work Life}

According to the EFA for Quality of Work Life Bartlett's test is 1700,371. KaiserMeyer-Olkin (KMO) Sampling Value is 0,888 , and it is sufficient to apply factor analysis method.

Table 3: Quality of Work Life Factor Analysis Table

\begin{tabular}{|c|c|c|c|c|c|c|c|}
\hline & $\begin{array}{l}\bar{\Xi} \\
\tilde{\Xi} \\
\tilde{\Xi} \\
\tilde{\Xi}\end{array}$ & 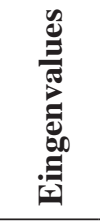 & 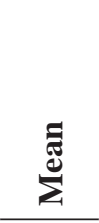 & 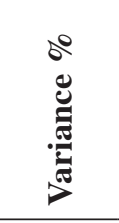 & 工 & 8 & $=$ \\
\hline Factor 1: Job & & 5,489 & 3,536 & 29,896 & 19,925 &, 870 & 000 \\
\hline $\begin{array}{l}\text { I feel that I am realizing my potential as } \\
\text { an expert in my line of work. }\end{array}$ &, 823 & & & & & & \\
\hline $\begin{array}{l}\text { I feel that I'm always learning new things } \\
\text { that help do my job better. }\end{array}$ &, 817 & & & & & & \\
\hline $\begin{array}{l}\text { I feel that my job allows me to realize my } \\
\text { full potential. }\end{array}$ & ,755 & & & & & & \\
\hline $\begin{array}{l}\text { This job allows me to sharpen my } \\
\text { Professional skills. }\end{array}$ & ,750 & & & & & & \\
\hline $\begin{array}{l}\text { There is a lot of creativity involved in my } \\
\text { job. }\end{array}$ & ,664 & & & & & & \\
\hline $\begin{array}{l}\text { People at hotel and/or within my } \\
\text { profession respect me as a Professional } \\
\text { and an expert in my field of work. }\end{array}$ & ,608 & & & & & & \\
\hline I feel appreciated at work at . &, 599 & & & & & & \\
\hline Factor 2: Working Condition & & 1,635 & 3,337 & 24,908 & 81,301 & ,802 & ,000 \\
\hline $\begin{array}{l}\text { I am satisfied with what I'm getting paid } \\
\text { for my work. }\end{array}$ & ,779 & & & & & & \\
\hline $\begin{array}{l}\text { I feel that my job at (name of the } \\
\text { organization) is secure for life. }\end{array}$ & ,768 & & & & & & \\
\hline My job does well for my family. & 679 & & & & & & \\
\hline My job provides good health benefits. & ,660 & & & & & & \\
\hline I feel physically safe at work. & ,638 & & & & & & \\
\hline $\begin{array}{l}\text { I have enough time away from work to } \\
\text { enjoy other things in life }\end{array}$ &, 554 & & & & & & \\
\hline
\end{tabular}

Kaiser-Meyer-Olkin =0,888; Bartlett's Test of Sphericity =1700,371; Cumulative Variance: 54,803 
When the Table 3 for the quality of work life is analysed, it is seen that data split up two dimension. These dimensions are identified respectively as job and working conditions. QWL first dimension jobs' mean is 3,536 and second dimension working conditions' mean is 3,337. Participants remarks all the two dimension are positive.

\subsection{EFA for the Wellbeing}

The Factor Analysis for Wellbeing Bartlett's Test Result is 1081,787, and KaiserMeyer-Olkin (KMO) Sampling Value is 0,867 . When the Table 2 for the wellbeing is analysed, it is seen that data split up one dimension. Participant ranks mean is 3,171 , it means participant wellbeing is good.

Table 4: Wellbeing Factor Analysis Table

\begin{tabular}{|c|c|c|c|c|c|c|c|}
\hline & $\begin{array}{l}\bar{\Xi} \\
\bar{\Xi} \\
\ddot{\Xi} \\
\ddot{\Xi}\end{array}$ & 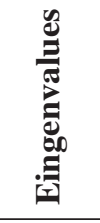 & స్త & 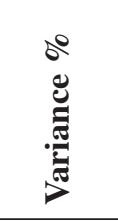 & 工 & 8 & 2 \\
\hline Factor: Wellbeing & & 4,084 & 3,171 & 58,344 & 95,412 & .877 & 000 \\
\hline I am satisfied with my life. &, 821 & & & & & & \\
\hline $\begin{array}{l}\text { So far I have gotten the important } \\
\text { things I want in life. }\end{array}$ & ,798 & & & & & & \\
\hline The conditions of my life are excellent. & ,790 & & & & & & \\
\hline In most ways my life is close to my ideal. & ,780 & & & & & & \\
\hline I often feel satisfy. & ,756 & & & & & & \\
\hline I often feel happy. & ,719 & & & & & & \\
\hline $\begin{array}{l}\text { If I could live my life over, I would } \\
\text { change almost nothing. }\end{array}$ & 671 & & & & & & \\
\hline
\end{tabular}

Kaiser-Meyer-Olkin =0,867; Bartlett's Test of Sphericity $=1081,787$; Cumulative Variance: 58,344

\subsection{Correlation and Regression Analysis of Co-Worker Support, QWL and Wellbeing}

Correlation analysis is carried out in order to see the relation between coworker support; work life quality and wellbeing. The results of the coworker support; work life quality and wellbeing correlation analysis is seen at Table 4 . All three variables correlated with each other high and positively. The highest positive correlation seems to be between quality of work life's factor "working condition" and wellbeing. The second highest positive correlation is between coworker support and quality of work life's factor "job". 
Table 5: Coworker Support; Work Life Quality and Wellbeing Correlation Table

\begin{tabular}{lcccc}
\hline & $\begin{array}{c}\text { Coworker } \\
\text { Support }\end{array}$ & $\begin{array}{c}\text { Quality of } \\
\text { Work Life1 }\end{array}$ & $\begin{array}{c}\text { Quality of } \\
\text { Work Life2 }\end{array}$ & Wellbeing \\
\hline Coworker Support & 1 & & & \\
\hline Quality of Work Life1 &, $511^{* *}$ & 1 & & \\
\hline Quality of Work Life2 &, $441^{* *}$ &, $491 * *$ & 1 & \\
\hline Wellbeing &, $473 * *$ &, $458 * *$ &, $547 * *$ & 1 \\
\hline
\end{tabular}

**The correlation is significant at the ,001 level.

To see the effect of the coworker support, and QWL on wellbeing, regression analyse have been used. As seen on the table model summary, 38,3\% of the change in wellbeing is included independent variables in the model. The relationship between variables is high ( $\mathrm{R}$ : $0,619)$ and positively.

Table 6: Coworker Support, Work Life Quality and Wellbeing Regression Model Summary Table

\section{Model Summary}

\begin{tabular}{ccccc}
\hline Model & R & R Square & $\begin{array}{c}\text { Adjusted R } \\
\text { Square }\end{array}$ & $\begin{array}{c}\text { Std. Error of the } \\
\text { Estimate }\end{array}$ \\
\hline 1 &, $619^{\mathrm{a}}$ &, 383 &, 377 &, 64429 \\
\hline
\end{tabular}

a Predictors: (Constant), QWL2, Coworker Support, QWL1

The regression analysis results are presented on Table 7. As in the case of table, relatively important variable in explaining wellbeing is QWL's second factor which is "employees' working condition" (Beta: 0,367). The second variable which effects wellbeing is coworker support (Beta: 0,230), and the third one is QWL's job factor (Beta: 0,160).

Table 7: Coworker Support; Work Life Quality and Wellbeing Regression Table

\begin{tabular}{|c|c|c|c|c|c|c|}
\hline \multicolumn{7}{|c|}{ oefficients $^{\text {a }}$} \\
\hline \multirow{2}{*}{\multicolumn{2}{|c|}{ Model }} & \multicolumn{2}{|c|}{ Unstandardized Coefficients } & \multirow{2}{*}{$\begin{array}{c}\text { Standardized } \\
\text { Coefficients } \\
\text { Beta } \\
\end{array}$} & \multirow[t]{2}{*}{$\mathbf{t}$} & \multirow[t]{2}{*}{ Sig. } \\
\hline & & B & Std. Error & & & \\
\hline \multirow{4}{*}{1} & (Constant) & , 489 & ,207 & & 2,366 & ,019 \\
\hline & Coworker & ,268 & ,062 & ,230 & 4,353 & ,000 \\
\hline & $\begin{array}{l}\text { Support } \\
\text { QWL1 }\end{array}$ &, 130 & ,044 & , 160 & 2,942 & ,003 \\
\hline & QWL2 & ,369 & ,052 & ,367 & 7,052 & ,000 \\
\hline
\end{tabular}

a Dependent Variable: Wellbeing 
The table shows that a unit increase in QLW2 leads to an increase of 0.369 in wellbeing. And one unite increase in coworker support leads to increase in wellbeing is 0,268 . The sigma values all indicate that the relations are significant $(\operatorname{Sig} \leq 0,05)$.

\section{Conclusions}

The study objective was determining the relation between coworker support, quality of work life and wellbeing in hotels. Correlation and regression analysis were applied to collected data for the study. There has been, if any, very limited research relationship between coworker support, QWL and wellbeing of hotel employees. It is estimated from the results of the study that there is a positive and significant relationship between coworker support, QWL and wellbeing

This study demonstrated and in addition confirmed that coworker support does have effect on employee wellbeing. The study findings are coherent with past researchs. For example, Sloan (2012), and Simon et al., (2010) reported that there is positive effect of coworker support on worker wellbeing. And also quality of work life's each two factors have effect on employee wellbeing. These findings support the findings of Sirgy et al.,(2001) and Rathi's (2010) researchs. Quality of work life is found to be an important predictor of employee's well-being.

Results suggest that employees who are supported by co-worker, and when QWL is high their wellbeing getting high. Human resource managers are well-advised to establish environments conducive to enhancing coworkers' evaluations of one another (Simon et al., 2010). In addition, working condition effect in wellbeing is higher than co-worker support and job. Human resource managers can prepare alternative work arrangements, employment benefits, ancillary programs to improve the quality of life (Sirgy et al.,2008). Results can be utilized as a guideline for establishing human resource management practices.

The limitation of this study, sample may not be generalizable to the population of the hotels employee in Turkey. Future research should examine whether positive outcomes of coworker support, QWL and wellbeing in employee attitudes.

\section{References}

Aerden, K. V., Moors, G., Levecque, K. \& Vanroelen, C. (2015). The relationship between employment quality and work-related well-being in the European labor force. Journal of Vocational Behavior, 86, 66-76.

Akoğlan Kozak, M. (1999). Konaklama sektöründe kariyer planlama yöntemleri ve uygulamada karşılaşılan sorunlar üzerine bir araştırma, Anatolia: Turizm Araştırmaları Dergisi, 10 , 53-66.

Andrews, F. \& Withey, S. (1976). Social Indicators of well being: America's perception of life quality. New York: Plenum Press.

Barron, P., Maxwell, G., Broadbridge, A. \& Ogden, S. (2007). Careers in hospitality management: Generation Y's experiences and perceptions. Journal of Hospitality and Tourism Management, 14(2), 119-128. 
Baum, T. (2007). Human resources in tourism: Still waiting for change. Tourism Management, 28, 1383-1399.

Bergboma, B. \& Kinnunen, U. (2014). Immigrants and host nationals at work: Associations of co-worker relations with employee well-being. International Journal of Intercultural Relations, 43, 165-176.

Buzinde, C. N., Kalavar, J. M. \& Melubo, K. (2014). Tourism and community well-being: The case of the Maasai in Tanzania. Annals of Tourism Research, 44, 20-35.

Chamberlain, L. J. \& Hodson, R. (2010). Toxic work environments: What helps and what hurts. Sociological Perspectives, 53(4), 455-478.

Chiaburu, D. S. \& Harrison, D. A. (2008). Do peers make the place? Conceptual synthesis and meta-analysis of co-worker effects on perception, attitudes, OCBs, and performance. Journal of Applied Psychology, 93, 1082-1103.

Chen, Y., Tjosvold, D. \& Pan, Y. (2010). Collectivist team values for Korean-Chinese coworker relationships and job performance. International Journal of Intercultural Relations, 34(5), 475-481.

Cobb, S. (1976). Social support as a moderator of life stress. Psychosomatic Medicine, 38(5), 300-314.

Dann, D. (1990). The nature of managerial work in the hospitality industry. International Journal of Hospitality Management, 9(4), 319-334.

Diener, E., Suh, E. M., Lucas, R. E. \& Smith, H. L. (1999). Subjective well-being: Three decades of progress. Psychological Bulletin, 125, 276-302.

Enz, C. A. \& Siguaw, J. A., (2000). Best practices in human resources. Cornell Hotel and Restaurant Administration Quarterly, 41(1), 48-61.

Gilbert, D. \& Abdullah, J. (2004). Holidaytaking and the sense of well-being. Annals of Tourism Research, 31(1), 103-121.

Giray, M. D. \& Şahin, D. N. (2012). Algılanan örgütsel, yönetici ve çalışma arkadaşları desteği ölçekleri: Geçerlik ve güvenirlik çalışması. Türk Psikoloji Yazıları, 15(30), 1-9.

Hian, C. C. \& Einstein, W. O., (1990). Quality of work Life (QWL): What can unions do? SAM Advanced Management Journal, 55(2), 17-22.

Huang, T-C., Lawyer, J. \& Lei, C-Y. (2007). The effects of quality of work life on commitment and turnover Intention. Social Behavior and Personality, 35(6), 735-750.

Kale, E. (2015). Lider desteği ve iş arkadaşları desteğinin iş performansı üzerine etkileri: İş tatmini ve yaşam tatmininin aracı rolü. International Journal of Economic and Administrative Studies, 7(14), 103-120.

Kandasamy, I. \& Ancheri, S. (2009). Hotel employees' expectations of QWL: A qualitative study. International Journal of Hospitality Management, 28, 328-337.

Karatepe, O. M., Keshavarz, S. \& Nejati, S. (2010). Do core self-evaluations mediate the effect of coworker support on work engagement? A study of hotel employees in Iran. Journal of Hospitality and Tourism Management, 17(1), 62-71.

Ladd, D. \& Henry, R. (2000). Helping coworkers and helping the organization: The role of support perceptions, exchange ideology, and conscientiousness. Journal of Applied Social Psychology, 30, 2028-2049. 
Lee, Y. W., Dai, Y. T., Park, C. G. \& Mccreary, L. L. (2013). Predicting quality of work life on nurses' intention to leave. Journal of Nursing Scholarship, 45, 160-168.

Lee, K-H., Choo, S-W, \& Hyun, S. S. (2016). Effects of recovery experiences on hotel employees' subjective well-being. International Journal of Hospitality Management, $52,1-12$.

Limpanitgul, T., Boonchoo, P.\& Photiyarach, S. (2014). Coworker support and organisational commitment: A comparative study of Thai employees working in Thai and American airlines. Journal of Hospitality and Tourism Management, 21, 100-107.

Limpanitgul, T., Robson, M. J., Gould-Williams, J. \& Lertthaitrakul, W. (2013). Effects of coworker support and customer cooperation on service employee attitudes and behaviour: Empirical evidence from the airline industry. Journal of Hospitality and Tourism Management, 20, 23-33.

Lin, Y.S., Huang, W-S., Yang, C-T. \& Y Chiang, M-J. (2014). Work-leisure conflict and its associations with well-being: The roles of social support, leisure participation and job burnout. Tourism Management, 45, 244-252.

May, B., Lau, R. \& Johnson, S. K. (1999). A longitudinal study of quality of work life and business performance. South Dakota Business Review, 58 (2), 1-7.

Meyer, J. P. \& Maltin, E. R. (2010). Employee commitment and well-being: A critical review, theoretical framework and research agenda. Journal of Vocational Behavior, 77(2), 323-337.

Monnot, M. J. \& Beehr, T. A. (2014). Subjective well-being at work: Disentangling source effects of stress and support on enthusiasm, contentment, and meaningfulness. Journal of Vocational Behavior, 85(2), 204-218.

Mosadeghrad, A. M. (2013). Quality of working life and turnover intentions: implications for nursing management. International Journal of Research in Nursing, 4(2), 47-54.

Nelson, K., Boudrias, J-S., Brunet, L., Morin, D., De Civita, M., Savoie, A. \& Alderson, M. (2014). Authentic leadership and psychological well-being at work of nurses: The mediating role of work climate at the individual level of analysis. Burnout Research, $1(2), 90-101$.

$\mathrm{Ng}, \mathrm{T}$. W. H. \& Sorensen, K. L. (2008). Toward a further understanding of the relationships between perceptions of support and work attitudes: A meta-analysis. Group \& Organization Management, 33, 243-268.

Rathi, N. (2010). Relationship of quality of work life with employees psychological wellbeing. International Journal of Business Insights \& Transformation, 53-60.

Roan, A. M. \& Diamond, C. (2003). Starting out : the quality of working life of young workers in the retail and hospitality. Industries in Australia, 11(2), 91-120.

Rumens, N. (2009). Firm friends: Exploring the supportive components in gay men's workplace friendships. Sociological Review, 58, 135-155.

Simon, L. S., Judge, T.A. \& Halvorsen-Ganepola, M. D. K. (2010). In good company? A multistudy, multi-level investigation of the effects of coworker relationships on employee well-being. Journal of Vocational Behavior, 76, 534-546. 
Sirgy M. J., Efraty, D., Siegel P. \& Lee D.J. (2001). A new measure of quality of work life (QWL) based on need satisfaction and spillover theory. Social Indicators Research, 55, 241-302.

Sloan, M. M. (2012). Unfair treatment in the workplace and worker well-being: the role of coworker support in a service work environment. Work and Occupations, 39, 3-34.

Susskind, A. M., Kacmar, K. M. \& Borchgrevink, C. P. (2003). Customer service providers' attitudes relating to customer service and customer satisfaction in the customer-server exchange (CSX). Journal of Applied Psychology, 88(1), 179-87.

Wood, R. C. (1997). Working in hotels and catering. London: International Thomson Business Press.

Wan, Y. K. P. \& Chan, S. H. J. (2013). Casino employees' perceptions of their quality of work life. International Journal of Hospitality Management, 34, 348-358.

Wright, T. A. (2010). The role of psychological well-being in job performance, employee retention and cardiovascular health. Organizational Dynamics, 39(1), 13-23. 
